\title{
Physical Activity Interventions for Primary Prevention in Adults: A Systematic Review of Randomized Controlled Trial-Based Economic Evaluations
}

Mattli, Renato ; Farcher, Renato ; Syleouni, Maria-Eleni ; Wieser, Simon ; Probst-Hensch, Nicole ; Schmidt-Trucksäss, Arno ; Schwenkglenks, Matthias

Abstract: BACKGROUND: Physical inactivity is a worldwide pandemic associated with major chronic diseases. Given limited resources, policy makers are in need of physical activity interventions that provide best value for money.

DOI: https://doi.org/10.1007/s40279-019-01233-3

Posted at the Zurich Open Repository and Archive, University of Zurich ZORA URL: https://doi.org/10.5167/uzh-178405

Journal Article

Accepted Version

Originally published at:

Mattli, Renato; Farcher, Renato; Syleouni, Maria-Eleni; Wieser, Simon; Probst-Hensch, Nicole; SchmidtTrucksäss, Arno; Schwenkglenks, Matthias (2020). Physical Activity Interventions for Primary Prevention in Adults: A Systematic Review of Randomized Controlled Trial-Based Economic Evaluations. Sports Medicine, 50(4):731-750.

DOI: https://doi.org/10.1007/s40279-019-01233-3 


\section{Physical activity interventions for primary prevention in}

\section{adults: a systematic review of randomized controlled trial- based economic evaluations}

Short title/running head: RCT-based economic evaluations of physical activity interventions

Renato Mattli ${ }^{1,2}$, Renato Farcher ${ }^{2}$, Maria-Eleni Syleouni ${ }^{2}$, Simon Wiese ${ }^{2}$, Nicole ProbstHensch $^{3,4}$, Arno Schmidt-Trucksäss ${ }^{5}$, Matthias Schwenkglenks ${ }^{1}$

${ }^{1}$ Institute of Pharmaceutical Medicine (ECPM), University of Basel, Klingelbergstrasse 61, 4056 Basel, Switzerland

${ }^{2}$ Winterthur Institute of Health Economics, Zurich University of Applied Sciences, Gertrudstrasse 15, 8401 Winterthur, Switzerland

${ }^{3}$ Swiss Tropical and Public Health Institute, Socinstrasse 57, 4051 Basel, Switzerland

${ }^{4}$ University of Basel, Petersplatz 1, 4001 Basel, Switzerland

${ }^{5}$ Division of Sports and Exercise Medicine, Department of Sport, Exercise and Health,

University of Basel, Mittlere Allee 18, 4052 Basel, Switzerland

Corresponding author:

Renato Mattli, Institute of Pharmaceutical Medicine (ECPM), University of Basel, Klingelbergstrasse 61, 4056 Basel, Switzerland, renato.mattli@unibas.ch, tel. +41612071954, fax +41589357892 


\section{Abstract}

Background: Physical inactivity is a worldwide pandemic associated with major chronic diseases. Given limited resources, policy makers are in need of physical activity interventions that provide best value for money.

Objective: To summarize evidence from RCT-based economic evaluations of primary prevention physical activity interventions in adult populations outside the workplace setting.

Design: Systematic review of health economic evaluations. Incremental cost-effectiveness ratios (ICERs) in US\$ per MET-hour gained were estimated on the basis of mean differences in intervention costs and standardized effects between intervention and control groups.

Data sources: Identification of relevant studies via systematic searches in electronic databases (MEDLINE, Embase and NHSEED).

Eligibility criteria: Cost-effectiveness analyses in which all data (except unit costs) came from one RCT investigating physical activity interventions for primary prevention or health promotion in an adult population in high-income countries.

Results: In twelve eligible studies, 22 interventions were investigated. Interventions were based on advice, goal setting and follow-up support, exercise classes, financial incentives or teaching on behavioral chiange. The ICER varied widely among the interventions and four interventions showed an ICER below the applied benchmark of US $\$ 0.44$ to US\$0.63 per MET-hour gained. These four interventions were based on individualized advice via print or web.

Conciusion: We found evidence from RCTs indicating cost-effectiveness of some physical activity interventions for primary prevention in adults. However, the majority of interventions assessed would not be cost-effective according to the benchmark applied. Furthermore, our study showed that trial-based evidence on cost-effectiveness of physical activity interventions is scarce. Therefore, we recommend that future studies investigating the 
efficacy or effectiveness of such interventions consider costs as an additional outcome and assess cost-effectiveness.

\section{Key points}

- We found evidence from RCTs indicating cost-effectiveness of some physical activity interventions for primary prevention in adults. However, cost-effectiveness resulis varied widely among interventions. Four interventions that delivered individualized advice via print or web showed best value (physical activity gains) for money (intervention costs).

- Our study shows that trial-based evidence on cost-effectiveness of physical activity interventions is relatively scarce.

- We recommend that future studies investigating the efficacy or effectiveness of interventions aimed at increasing physical activity consider costs as an additional outcome and assess cost-effectiveness. 


\section{Introduction}

Physical inactivity is a worldwide pandemic that causes substantial health and economic burden [1-3]. Established health consequences of physical inactivity include cardiovascular diseases, diabetes and different types of cancer [3]. However, there is growing evidence that physical inactivity is also related to musculoskeletal and mental health problems [4-6], which has not been explored in the majority of studies. This may result in an underestimation of the true burden of physical inactivity. The substantial burden of physical inactivity calls for interventions aiming to increase physical activity.

With limited resources available, policy makers are interested in interventions that provide best value for money. Therefore, interventions aiming to reduce physical inactivity should not only prove effectiveness on health outcomes but also cost-effectiveness. Economic evaluation studies compare costs and outcomes of an interyention with a comparator. In the area of physical activity, the comparator is often doing nothing, non-physical activity related advice or standard physical activity advice [7].

There are two different approaches in economic evaluations: trial-based economic evaluations and model-based economic evaluations [8]. In a trial-based economic evaluation, costs are measured within a randomized controlled trial $(R C T)$ investigating the effect of the intervention [9]. In a model-based economic evaluation, data on the effect and the costs from different sources are combined in a decision-analytic model [10]. Both methodological approaches have strengths and weaknesses [9-11]. The main strengths of a trial-based economic cvaluation are related to the methodological strength of RCTs, i.e. the exclusion of potential biasing factors [12]. However, RCTs have weaknesses when directly used for policy making that are related to the efficacy versus effectiveness discussion [12]: Areas of potential concern include choice of comparator, protocol-driven costs and outcomes, artificial environment, intermediate versus final outcomes, inadequate participant follow-up, and selected patient and provider populations [12]. Model-based economic evaluations have the strength that they can synthesize the best evidence available in case relevant head-to-head 
clinical trials are missing, costs were not measured within trials, intermediate endpoints were captured or trial follow-up was short-term [8]. Nevertheless, inappropriate use of clinical data, bias in observational data, difficulties of extrapolation and concerns about transparency or validity of models are major concerns [8]. These strengths and weaknesses make it evident that for policy making reasons the two methods are better used complementarily than alternatively [13]. In any case, the review of available evidence, e.g. trial-based economic evaluations, remains a prerequisite for conducting model-based economic evaluations.

Several systematic reviews have investigated the cost-effectiveness of physical activity interventions but most of these reviews focused on specific settings (e.g. school, workplace, community) and did not pay much attention to the methodological approaches (trial-based or model-based) chosen in the identified economic evaluations [14]. The availability of trialbased economic evaluations of physical activity interventions seems to be limited [7, 15-17], and to the best of our knowledge, no systematic review has focused on this topic.

Consequently, this study aims to systematically review trial-based economic evaluations of interventions to reduce physical inactivity $n$ the general adult population. 


\section{Methods}

We conducted our study according to current recommendations for systematic reviews of health economic evaluations [18-20].

\subsection{Eligibility criteria}

We defined the following inclusion criteria:

Population: General adult population ( $\geq 18$ years) in high-income countries as defined according to the World Bank [21]. We focused on populations in which physical activity would be considered to be primary prevention or health promotion. Conseque tly we excluded studies investigating physical activity as secondary or tertiary prevention in patients with diseases such as stroke, diabetes, obesity, COPD, multiple sclerosis or mental health issues. As we focused on interventions that can be implemented on a population-level, we excluded studies on specific populations such as worksite populations, students or soldiers.

Intervention: Any intervention aimed to increase physical activity.

Comparator: No intervention (doing nothing), non-physical activity related advice or any other intervention aimed to increase physical activity.

Outcomes: Effectiveness (e.g. change in physical activity minutes, change in walking time, change in steps per clay, change in the number of physically active individuals) and intervention costs. Wve excluded studies that did not report specific physical activity outcomes, e.g studies only reporting quality-adjusted life-years as part of pure cost-utility analyses

Study design: Cost-effectiveness analyses in which all data (except unit costs) came from one RCT of any follow-up duration. Consequently, we excluded health economic modelling studies and cost-effectiveness analyses from trials with a design other than RCT.

We focused on recently published studies since the year 2000 written in English or German. 


\subsection{Search strategy}

We searched for studies using the following electronic databases: MEDLINE (via Pubmed), Embase and NHSEED. The search strategy was defined using the PRESS checklist [22]. As detailed in Table 1, we created a search string for physical activity and one for economic evaluations. These strings were then combined to identify economic evaluations of physical activity interventions. The search strategy was validated with the cost-effectiveness studies identified by Foster et al. [16]. The final search was conducted on 31 July 2019.

Table 1 Detailed search strategy

\begin{tabular}{|c|c|}
\hline & Mesh/Emtree Search \\
\hline & $\begin{array}{l}\text { - Mesh (for Pubmed): Exercise [Mesh] (not one level higher (Motor Activity [Mesh]) as otherwise } \\
\text { getting many animal studies); Physical Fitness [Mesh] } \\
\text { Emtree for Embase: Physical activity; Physical inactivity Fitness }\end{array}$ \\
\hline & Expressions from titles/abstracts used to describe phy icai activity - Keyword Search \\
\hline $\begin{array}{c}\text { Concept } 1 \\
\text { physical activity }\end{array}$ & 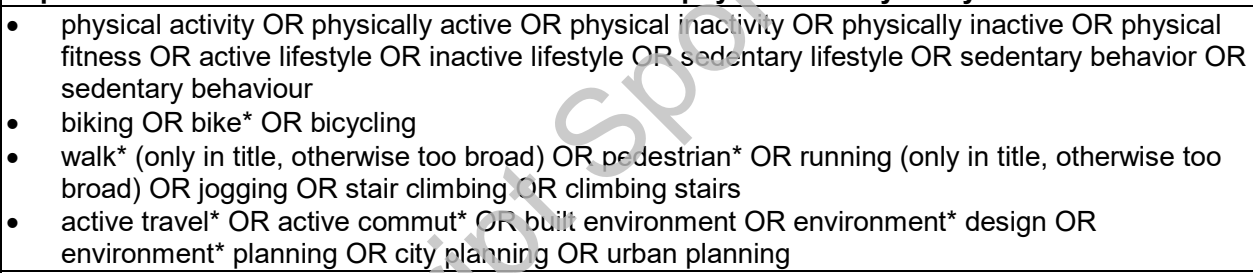 \\
\hline & Mesh/Emtree Search \\
\hline $\begin{array}{c}\text { Concept } 2 \\
\text { economic evaluations }\end{array}$ & 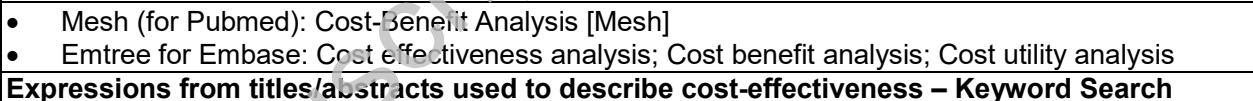 \\
\hline & $\begin{array}{l}\text { aly* OR economic evaluat } \\
{ }^{*} \text { OR cost-benefit* OR cos }\end{array}$ \\
\hline
\end{tabular}

\subsection{Study selection}

Identified studies were exported into Endnote and duplicates were removed. Prior to the screening of the identified studies, training sessions took place to ensure high consistency between reviewers. Afterwards, two reviewers (RM, RF) screened all studies separately. Title/abstracts were screened first, followed by a full-text screening. Disagreements between reviewers after screening title/abstracts and the assessment of full-text were resolved by consensus. Unclear cases were discussed with a third reviewer (MS).

\subsection{Data extraction}

We extracted data on the study design including random sequence generation, allocation concealment and blinding. Furthermore, we collected information regarding the definition of 
the study population, details about the intervention and control groups, outcome definition and measurement, and results. A data extraction form was created in Microsoft Excel, pilot tested independently by two reviewers and subsequently adapted to ensure all relevant data being captured. Data were then extracted by one reviewer and confirmed by a second reviewer. Disagreements were again resolved by consensus. In case required information was not reported in the publication, data were extracted from additional publications relating to the same study, e.g. study protocols.

\subsection{Risk of bias and quality assessment}

Risk of bias was assessed using the criteria from the Cochrane risk of blas tool and the consensus on health economics criteria (CHEC) list [23, 24]. Two reviewers evaluated the selected studies independently and any disagreement was again resolved by consensus. As in previous systematic reviews of interventions promoting physical activity, we did not rate studies on whether participants were blinded to their allocation to intervention or control groups [7], because it would be impossible to blind participants to a physical activity intervention. For the assessment of the performance bias, we therefore considered blinding of the personnel and if this may have affected the outcome. If publications from the same study were referenced, we also checked these additional references for information supporting the risk of bias assessment.

\subsection{Data synthesis}

The studies included in the review reported different physical activity outcomes. In order to compare the results between studies, effect measures were standardized. The standardized effect measure was the metabolic equivalent of task (MET) measured in MET-hours gained per person per day. One MET is defined as the resting energy expenditure, which is equivalent to an oxygen consumption of $3.5 \mathrm{ml} / \mathrm{kg} / \mathrm{min}$. The MET of an activity is a multiplicator of the resting energy expenditure and represents the intensity of an activity. To calculate the volume of physical activity we multiplied frequency by duration of physical activity as MET-hours. The formula by Wu et al. [17] was used to translate physical activity 
outcomes to MET-hours gained per person per day. For these calculations, 3.0 METs were assigned to moderate physical activity, 4.5 METs to moderate-to-vigorous physical activity and 6.0 METs to vigorous physical activity [17]. We choose these relatively low values to be consistent with other studies in the field $[17,25]$ and because of the well-documented large overestimation of physical activity intensity by self-report [26-28]. Whenever possible, the results of a twelve-month follow-up interval were taken to make the studies comparable.

Physical activity interventions cause different types of costs, e.g. intervention costs, costs to participants, healthcare costs or production losses [29]. We therefore extracted the costs separately for each type. Cost types included in all studies (i.e. intervention costs) were used to compare costs between studies. The costs were converted to US dollars (US\$) using purchasing power parity conversion factors for the reference year [30]. Costs were then extrapolated to the year 2018 using the total consumer price index for the US [31].

We further calculated the mean differences in costs and outcomes between intervention and control as a basis for estimating the incremental cost-effectiveness ratio (ICER) in US\$ per MET-hour gained. The outcome in MET-hours per person per day was multiplied with the number of days of follow-up to make the outcome comparable to the costs and, therefore, allow us to compare interventions with different follow-up times. Wu et al. [17] used a benchmark of US\$0.50 to US\$1.00 per MET-hour gained to assess cost-effectiveness of physical activity interventions. This benchmark is based on the per capita health care costs of physical inactivity in the US and the recommendation for health-enhancing physical activity by the WHO [32]. This means at least 2.5 hours per week of physical activity with moderate intensity or 1.25 hours per week of physical activity with vigorous intensity [32]. We used the same approach as Wu et al. [17] but applied current health care costs and productivity losses of physical inactivity in Switzerland [33]. Based on the lower and upper bound of the 95\% uncertainty interval reported, we estimated a benchmark between US $\$ 0.44$ and US $\$ 0.63$ per MET-hour gained [33]. Swiss health care costs were extrapolated from 2013 to 2018 
according to the increase in per capita health care spending and productivity losses were extrapolated using the wage index [34, 35]. 


\section{Results}

\subsection{Study identification}

Our searches retrieved 5060 potentially relevant studies (Fig. 1). After removing 1288 duplicates, 3772 title/abstracts were screened. Many studies had to be excluded as they investigated populations not matching our inclusion criteria or the study design was not an RCT. After screening of title and abstract, 36 full-text publications were assessed for eligibility. Of these 36 publications, 24 were excluded because the population was not fulfilling our inclusion criteria (10 publications), the physical activity (5 publica ions) or cost outcome (6 publications) was not reported in sufficient detail, the study vas a model-based evaluation of an initial trial that was included in our analysis (1 publication), the study investigated a follow-up intervention after an initial physical activity intervention (1 publication), the journal publication reported a study that was included in our analysis based on the earlier published and more detailed Health Technology Assessment report (1 publication). Twelve studies were included in the final evaluation.

\subsection{Description of included studies}

Details of the twelve included studies are provided in Table 2. Three trial-based costeffectiveness analyses were conducted in New Zealand [36-38], three in the UK [39-41], three in the USA [42-44], two in the Netherlands [45, 46], and one in Australia [47]. Eight studies recruited the participants through GPs [36-41, 46, 47], three studies used different channels for advertisements [42-44] and one study recruited participants with invitation letters [45]. The mean age of participants in the twelve studies ranged from 45 years to 74 years. Female participants were more frequent in all of the studies except for the Dutch study conducted by van Keulen et al. [46], in which $45 \%$ of the participants were female. Four studies were clustered RCTs [37, 39, 40, 45]. In three studies, the trial arms had less than 100 participants $[42,44,47]$. All the other studies had more than 100 participants per arm. 
Table 2 Overview on included studies

\begin{tabular}{|c|c|c|c|c|c|c|c|}
\hline Reference & Country & Population $^{\mathrm{a}}$ & Intervention $^{\mathbf{b}}$ & Control $^{\mathrm{C}}$ & Follow-up ${ }^{d}$ & Effect meas ures & Cost measures \\
\hline $\begin{array}{l}\text { Harris et al. } \\
{[39]}\end{array}$ & UK & \begin{tabular}{|l|} 
Adults aged $45-74$ years \\
recruited by their GP by \\
invitation letter, physically \\
inactive, able to walk outside the \\
home and no contraindications \\
to increase moderate to vigorous \\
physical activity \\
Mean age (years): not reported; \\
range: $45-74$ \\
Males (\%): (1) 37 ; (2) 37 ; (C) 34 \\
\end{tabular} & $\begin{array}{l}\text { (1) pedometer, individual targets for step } \\
\text { counts over a period of } 12 \text { weeks and } \\
\text { dairy for daily step counts all provided by } \\
\text { post ( } n=339) \\
\text { (2) pedometer, individual targets for step } \\
\text { counts over a period of } 12 \text { weeks and } \\
\text { dairy for daily step counts all provided by } \\
\text { a nurse plus three individually tailored } \\
\text { physical activity consultations by a nurse } \\
\text { at week } 1,5 \text { and } 9(n=346)\end{array}$ & $\begin{array}{l}\text { Doing nothing: } \\
\text { Participants were } \\
\text { advised to continue } \\
\text { their usual physical } \\
\text { activity and were not } \\
\text { offered the 12-week } \\
\text { intervention }\end{array}$ & 12 months & $\begin{array}{l}\text { Weekly minutes of } \\
\text { moderate to vigorous } \\
\text { physical activity (in } \geq 10- \\
\text { minute bouts) as } \\
\text { measured with 7-day } \\
\text { accelerometry with a } \\
\text { belt at the hip }\end{array}$ & $\begin{array}{l}\text { NHS perspective } \\
2 \text { types of costs: } \\
\text { intervention costs (set-up } \\
\text { costs and delivery costs), } \\
\text { healthcare costs }\end{array}$ \\
\hline $\begin{array}{l}\text { Ewald et al. } \\
{[47]}\end{array}$ & Australia & \begin{tabular}{|l|} 
Adults aged $>18$ years recruited \\
by their GP, average daily step \\
count lower than 7000 steps per \\
week, many participants with \\
inactivity-related health problems \\
Mean age (years): 57 \\
Males (\%): 30
\end{tabular} & $\begin{array}{l}\text { Physical activity behavior change } \\
\text { counseling delivered in two ways: } \\
\text { (1) five face-to-face visits with an } \\
\text { exercise physiologist }(n=68) \\
\text { (2) one face-to-face visit with an } \\
\text { exercise physiologist, followed by four } \\
\text { sessions delivered by phone }(n=64)\end{array}$ & $\begin{array}{l}\text { Standardized print } \\
\text { brochure encouraging } \\
\text { physical activity }(n=71)\end{array}$ & 12 months & $\begin{array}{l}\text { Step count for one week } \\
\text { with pedometer }\end{array}$ & $\begin{array}{l}\text { Payer perspective } \\
\text { Intervention costs }\end{array}$ \\
\hline $\begin{array}{l}\text { Golsteijn et } \\
\text { al. [45] }\end{array}$ & Netherlands & $\begin{array}{l}\text { Adults aged }>50 \text { years recruited } \\
\text { based on matched } \\
\text { neighborhoods from municipal } \\
\text { health council regions } \\
\text { Mean age (years): (1) } 63 ; \text { (2) } 64 ; \\
\text { (3) } 62 ;(4) 61 ; \text { (C) } 64 \\
\text { Males (\%): (1) } 46 ; \text { (2) } 45 ; \text { (3) } 52 ; \\
\text { (4) } 51 ; \text { (C) } 50\end{array}$ & $\begin{array}{l}\text { Computer-tailored physical activity } \\
\text { advice at three time-points ( } 2 \text { weeks, } 2 \\
\text { months and } 4 \text { months after baseline) } \\
\text { delivered as either print (mail) or veb } \\
\text { (website and email) and in either a basic } \\
\text { form (standard advice) or vith additional } \\
\text { environmental components (e.g., } \\
\text { walking and cycling routes and PA } \\
\text { possibilities and init atives in } \\
\text { participants' own neighborhood and } \\
\text { home exercises): } \\
(1) \text { prin -delivered basic ( } n=439) \\
(2) \text { print-cielivered environmental } \\
(n=435) \\
\text { (3) we b-based basic }(n=423) \\
\text { (4) web-based environmental }(n=432)\end{array}$ & \begin{tabular}{|l|} 
Doing nothing: \\
Participants in the \\
control group were \\
invited to complete 4 \\
questionnaires about \\
physical activity during \\
the upcoming year and \\
they were told that \\
they would receive \\
physical activity advice \\
after one year as a \\
reward for their \\
cooperation $(n=411)$
\end{tabular} & 12 months & $\begin{array}{l}\text { MET-hours per week } \\
\text { based on the Dutch } \\
\text { SQUASH [48] }\end{array}$ & $\begin{array}{l}\text { Societal perspective } \\
\text { Intervention costs (fixed } \\
\text { and variable), healthcare } \\
\text { costs, participant and } \\
\text { family costs (buying sports } \\
\text { equipment, paying } \\
\text { membership fees,...), } \\
\text { productivity losses }\end{array}$ \\
\hline
\end{tabular}




\begin{tabular}{|c|c|c|c|c|c|c|c|}
\hline $\begin{array}{l}\text { Iliffe et al. } \\
\text { [40] }\end{array}$ & UK & $\begin{array}{l}\text { Adults aged } \geq 65 \text { years recruited } \\
\text { by their GP with stable medical } \\
\text { conditions, living independently, } \\
\text { walking independently both } \\
\text { indoors and outdoors (with or } \\
\text { without a walking aid and without } \\
\text { help from another person) } \\
\text { Mean age (years): } 73 \\
\text { Males (\%): } 38\end{array}$ & $\begin{array}{l}2 \text { intervention arms: } \\
\text { (1) class-based exercise: FaME } \\
\text { program, weekly classes plus home } \\
\text { exercises for } 24 \text { weeks and encouraged } \\
\text { walking ( } n=387) \\
\text { (2) home-based exercise: OEP, home } \\
\text { exercises supported by peer mentors for } \\
24 \text { weeks and encouraged walking } \\
(n=411)\end{array}$ & $\begin{array}{l}\text { Doing nothing: } \\
\text { Participants in the } \\
\text { control group were not } \\
\text { offered either the OEP } \\
\text { or FaME program, but } \\
\text { were free to participate } \\
\text { in any other exercise } \\
\text { just as they would if } \\
\text { they were not } \\
\text { participating in the trial } \\
(n=458)\end{array}$ & \begin{tabular}{|l|}
12 months \\
after the end \\
of the \\
intervention \\
period
\end{tabular} & $\begin{array}{l}\text { Proportion reaching the } \\
\text { recommended physical } \\
\text { activity target of } 150 \\
\text { minutes of moderate to } \\
\text { vigorous physical } \\
\text { activity per week based } \\
\text { on the CHAMPS } \\
\text { questionnaire [49] }\end{array}$ & \begin{tabular}{|l|} 
NHS and participant \\
perspective \\
Setup and management of \\
the intervention; hire of \\
facilities; equipment; \\
human resources; travel \\
and phone expenses \\
related to delivering the \\
intervention; participants' \\
out-of-pocket expenses \\
related to exercising (incl. \\
FaME)
\end{tabular} \\
\hline $\begin{array}{l}\text { Leung et al. } \\
\text { [38] }\end{array}$ & \begin{tabular}{|l|} 
New \\
Zealand \\
(Auckland)
\end{tabular} & $\begin{array}{l}\text { Adults aged } \geq 65 \text { years recruited } \\
\text { by their GP from communities in } \\
\text { Auckland, who did not achieve } \\
\text { the recommended } 150 \text { minutes } \\
\text { of at least moderate physical } \\
\text { activity per week; } 97 \% \text { of } \\
\text { participants were of New } \\
\text { Zealand European ethnicity } \\
\text { Mean age (years): } 74 \\
\text { Males (\%): } 46\end{array}$ & $\begin{array}{l}\text { Face-to-face advice, step-related goal } \\
\text { setting, followed by phone counseling: } \\
\text { initial face-to-face advice on engaging in } \\
\text { physical activity from GP including goal } \\
\text { setting, followed up by } 3 \text { phone } \\
\text { counseling sessions by trained physical } \\
\text { activity counselors over } 3 \text { to } 4 \text { months. } \\
\text { Goal setting based on steps and } \\
\text { participants were encouraged to use } \\
\text { their pedometer to monitor steps. Goals } \\
\text { were handed to participants on a green } \\
\text { prescription card }(n=165)\end{array}$ & \begin{tabular}{|l|} 
Face-to-face advice, \\
time-related goal \\
setting, followed by \\
phone counseling: \\
Participants in the \\
control group received \\
the same intervention \\
as participants in the \\
intervention group with \\
the exception that \\
counseling focused on \\
accumulating physical \\
activity around time- \\
related goals rather \\
than step-related goals \\
(n=165)
\end{tabular} & 12 monins & $\begin{array}{l}\text { Minutes of weekly } \\
\text { leisure walking } \\
\text { assessed with the } \\
\text { Auckland Heart Study } \\
\text { Physical Activity } \\
\text { Questionnaire [50] }\end{array}$ & $\begin{array}{l}\text { Public health care system } \\
\text { and participant perspective } \\
\text { Three categories: (i) } \\
\text { Community care costs, } \\
\text { which included GPs, } \\
\text { nurses, physiotherapists, } \\
\text { other allied health } \\
\text { professionals, home help, } \\
\text { and the cost of the } \\
\text { pedometer. (ii) Exercise } \\
\text { and community care costs, } \\
\text { which included the prior } \\
\text { category plus all personal } \\
\text { sport and exercise } \\
\text { equipment and physical } \\
\text { activity costs. (iii) All costs, } \\
\text { which included the prior } \\
\text { category plus all hospital- } \\
\text { related costs such as } \\
\text { specialist consultations, } \\
\text { outpatient procedures and } \\
\text { inpatient stays. (Costs of } \\
\text { coordinating the GRx } \\
\text { program and of phone } \\
\text { counseling were excluded } \\
\text { as these costs were } \\
\text { common to both patient } \\
\text { groups) }\end{array}$ \\
\hline
\end{tabular}




\begin{tabular}{|c|c|c|c|c|c|c|c|}
\hline $\begin{array}{l}\text { Elley et al. } \\
{[36]}\end{array}$ & \begin{tabular}{|l|} 
New \\
Zealand
\end{tabular} & $\begin{array}{l}\text { Women aged } 40-74 \text { years } \\
\text { recruited by their GP and not } \\
\text { achieving } 30 \text { minutes of at least } \\
\text { moderate-intensity exercise such } \\
\text { as brisk walking on } 5 \text { days or } \\
\text { more per week } \\
\text { Mean age (years): } 59 \\
\text { Males (\%): } 0\end{array}$ & $\begin{array}{l}\text { Face-to-face advice, goal setting and } \\
\text { follow-up by a face-to-face meeting and } \\
\text { phone counseling: } 10 \text { minutes of brief } \\
\text { advice and a written exercise } \\
\text { prescription given by a primary } \\
\text { healthcare nurse, face-to-face follow-up } \\
\text { at } 6 \text { months and phone support for } 9 \\
\text { months from an exercise facilitator. The } \\
\text { recommended goal was at least } 30 \text { min } \\
\text { of moderate-intensity physical activity } \\
\text { five times per week ( } n=544)\end{array}$ & \begin{tabular}{|l|} 
Doing nothing: \\
Participants in the \\
control group received \\
usual care from GP \\
$(\mathrm{n}=545)$
\end{tabular} & 24 months & $\begin{array}{l}\text { Minutes of moderate or } \\
\text { vigorous physical } \\
\text { activity per week } \\
\text { assessed with the NZ } \\
\text { Physical Activity } \\
\text { Questio nnaire [51] }\end{array}$ & \begin{tabular}{|l|} 
Societal perspective \\
Direct and indirect costs \\
including program delivery \\
costs, participant exercise \\
costs, primary and \\
secondary care costs, \\
allied healthcare costs and \\
productivity costs
\end{tabular} \\
\hline $\begin{array}{l}\text { Van Keulen } \\
\text { et al. [46] }\end{array}$ & Netherlands & $\begin{array}{l}\text { Adults aged 45-70 years } \\
\text { recruited by their GP who failed } \\
\text { to meet at least two out of three } \\
\text { Dutch public health guidelines } \\
\text { (physical activity, fruit and } \\
\text { vegetable consumption), } 50 \% \\
\text { diagnosed as hypertensive } \\
\text { Mean age (years): } 57 \\
\text { Males (\%): } 55\end{array}$ & $\begin{array}{l}3 \text { intervention arms: } \\
\text { (1) TPC: four printed, tailored letters (1. } \\
\text { letter: } 4 \text { pages about physical activity, } 2 \text {. } \\
\text { and } 4 \text {. letter: } 5 \text { pages about fruits and } \\
\text { vegetables, } 3 \text {. letter: } 3 \text { pages about } \\
\text { physical activity) ( } n=405) \\
\text { (2) TMl: four phone calls, the order of } \\
\text { the conversation topics in the first and } \\
\text { third interviews could be chosen by } \\
\text { participants (if PA was preferred in the } \\
\text { first interview, fruit and vegetables } \\
\text { consumption was discussed in the } \\
\text { second and vice versa) ( } n=407) \\
\text { (3) Combined: two tailored print letters } \\
\text { and two phone motivational interviews, } \\
\text { the first letter and interview focused on } \\
\text { physical activity, the second letter and } \\
\text { interview on fruit and vegetabies } \\
\text { consumption ( } n=408)\end{array}$ & \begin{tabular}{|l|} 
Doing nothing: \\
Participants in the \\
control group received \\
one tailored letter after \\
the last follow-up \\
questionnaire $(n=409)$
\end{tabular} & $\begin{array}{l}73 \text { weeks } \\
\text { (approx } 17 \\
\text { mionths) }\end{array}$ & \begin{tabular}{|l|} 
Proportion reaching the \\
recommended physical \\
activity target of 150 \\
minutes of moderate to \\
vigorous physical \\
activity per week \\
measured with the \\
modified CHAMPS \\
physical activity \\
questionnaire [52] \\
(added to this was the \\
summary question of the \\
SQUASH [48])
\end{tabular} & $\begin{array}{l}\text { Payer and participant } \\
\text { perspective } \\
\text { Fixed and variable costs } \\
\text { involved in implementing } \\
\text { the intervention (e.g. } \\
\text { printing and mailing letters } \\
\text { for TPC, call charges for } \\
\text { TMI) and the costs of the } \\
\text { time invested by } \\
\text { participants }\end{array}$ \\
\hline
\end{tabular}




\begin{tabular}{|c|c|c|c|c|c|c|c|}
\hline \begin{tabular}{|l|} 
Finkelstein \\
et al. [42]
\end{tabular} & USA & $\begin{array}{l}\text { Adults aged } \geq 50 \text { years recruited } \\
\text { through advertisements in two } \\
\text { free local newspapers and a free } \\
\text { online website of classified ads, } \\
\text { self-reported as healthy and } \\
\text { sedentary (currently exercising } \\
\text { for less than } 2 \mathrm{~h} \text { per week and if } \\
\text { exercising, engaging in walking } \\
\text { as their primary form of exercise) } \\
\text { Mean age (years): (I) } 59 \text {; (C) } 61 \\
\text { Males (\%): (I) } 24 \text {; (C) } 27\end{array}$ & $\begin{array}{l}\text { Financial incentive: The intervention } \\
\text { group was offered } \$ 50 \text { for base } \\
\text { participation in the study as well as a } \\
\text { variable incentive payment depending } \\
\text { on participants' aerobic minutes during } \\
\text { each of the } 4 \text { weeks of the study: } \\
-\$ 0 \text { if averaging less than } 15 \text { aerobic } \\
\text { minutes per day each week } \\
-\$ 10 \text { if averaging at least } 15 \text { and less } \\
\text { than } 25 \text { aerobic minutes per day each } \\
\text { week } \\
-\$ 15 \text { if averaging at least } 25 \text { and less } \\
\text { than } 40 \text { aerobic minutes per day each } \\
\text { week } \\
-\$ 20 \text { if averaging } 40 \text { or more aerobic } \\
\text { minutes per day each week } \\
(n=21)\end{array}$ & \begin{tabular}{|l|} 
Fixed financial \\
incentive: The control \\
group received a fixed \\
payment of $\$ 75$ for \\
attending a $90-$ minute \\
kickoff meeting, \\
wearing a pedometer \\
daily and returning all \\
study materials $(n=30)$
\end{tabular} & 4 weeks & $\begin{array}{l}\text { Daily aerobic minutes } \\
\text { measured with } \\
\text { pedometers over } 4 \\
\text { weeks }\end{array}$ & $\begin{array}{l}\text { Payer perspective } \\
\text { Only costs due to } \\
\text { incentives were included in } \\
\text { the study }\end{array}$ \\
\hline $\begin{array}{l}\text { Sevick et al. } \\
\text { [44] }\end{array}$ & USA & \begin{tabular}{|l|} 
Adults aged $18-65$ years \\
recruited from the community \\
using advertisements in the \\
newspaper and in a local \\
hospital; participants were \\
considered as healthy but \\
sedentary (<90 minutes per \\
week of at least moderate or \\
vigorous physical activity) based \\
on a phone call from a research \\
assistant \\
Mean age (years): 45 \\
Males (\%): 18 \\
\end{tabular} & $\begin{array}{l}2 \text { intervention arms. Participants in both } \\
\text { arms mailed in physical activity logs and } \\
\text { brief surveys each month, which were } \\
\text { used to generate individualized } \\
\text { feedback with the goal to increase } \\
\text { physical activity. Feedback was } \\
\text { communicated to participants either via } \\
\text { mail or phone: } \\
\text { (1) a phone-based, individualized } \\
\text { motivationally-tailored feedback } \\
\text { intervention ( } n=80) \\
\text { (2) a print-based, individualized } \\
\text { motivationally-tailored foedback }(n=81)\end{array}$ & \begin{tabular}{|l|} 
Doing nothing: The \\
participants in the \\
control group received \\
mailings un elated to \\
physical activity on the \\
same schedule as \\
phone and print \\
paiticipants, as well as \\
a packet of health \\
information at the \\
beginning of the study \\
$(n=78)$
\end{tabular} & 12 months & $\begin{array}{l}\text { Minutes of physical } \\
\text { activity per week as } \\
\text { assessed in a 7-day } \\
\text { physical activity recall } \\
\text { interview [53] }\end{array}$ & $\begin{array}{l}\text { Payer perspective } \\
\text { Intervention costs } \\
\text { including those costs that } \\
\text { would be borne by and } \\
\text { outcomes that would be } \\
\text { relevant to a health plan or } \\
\text { insurer offering the } \\
\text { intervention as part of their } \\
\text { covered services }\end{array}$ \\
\hline $\begin{array}{l}\text { Isaacs et al. } \\
\text { [41] }\end{array}$ & UK & \begin{tabular}{|l|} 
Adults aged $40-74$ years \\
recruited from their GP, not \\
currently physically active, with \\
at least one cardiovascular risk \\
factor but without pre-existing \\
overt cardiovascular disease, \\
uncontrolled hypertension, \\
uncontrolled insulin-dependent \\
diabetes, psychiatric conditions \\
or physical disabilities that would \\
prevent participation in an \\
exercise class \\
Mean age (years): 57 \\
Males (\%): 33
\end{tabular} & $\begin{array}{l}\text { 10-week physical acti ity program with } \\
\text { advice on how to continue and financial } \\
\text { incentive: } \\
\text { (1) a 10-week program of supervised } \\
\text { exercise classes, two to three times a } \\
\text { week in a local leisure center }(n=317) \\
\text { (2) a } 0 \text {-week instructor-led walking } \\
\text { program, two to three times a week } \\
\text { (n-311) } \\
\text { Both with provision for continuing } \\
\text { exercise at the end of the program. This } \\
\text { lincluded advice on how to continue } \\
\text { being active and a financial incentive (a } \\
\text { book of } 20 \text { half-price tickets for the } \\
\text { leisure center). No charge was made to } \\
\text { attend any of the exercise sessions } \\
\text { during the } 10 \text {-week period }\end{array}$ & \begin{tabular}{|l|} 
Individualized advice: \\
The advice-only \\
control group received \\
tailored advice and \\
information on physical \\
activity including \\
information on local \\
exercise facilities. After \\
6 months the control \\
group were re- \\
randomized to one of \\
the other trial arms \\
$(\mathrm{n}=315)$
\end{tabular} & 12 months & $\begin{array}{l}\text { Minutes of moderate } \\
\text { and/or vigorous activity } \\
\text { per week as measured } \\
\text { with a 7-day recall } \\
\text { questionnaire [54] }\end{array}$ & $\begin{array}{l}\text { NHS and participant } \\
\text { perspective } \\
3 \text { types of costs: } \\
\text { intervention costs } \\
\text { (facilities, exercise } \\
\text { trainers, administrative } \\
\text { support), participants costs } \\
\text { (time, travel, pay for } \\
\text { childcare, equipment), } \\
\text { healthcare costs }\end{array}$ \\
\hline
\end{tabular}




\begin{tabular}{|c|c|c|c|c|c|c|c|}
\hline \begin{tabular}{|l} 
Elley et al. \\
[37]
\end{tabular} & \begin{tabular}{|l|} 
New \\
Zealand
\end{tabular} & \begin{tabular}{|l|} 
Adults aged $40-79$ years \\
recruited by their GP, "less \\
active" meaning those who were \\
not achieving the recommended \\
2.5 hours of at least moderate \\
activity per week \\
Mean age (years): (I) 57 ; (C) 59 \\
Males (\%): (I) $33 ;$ (C) 34
\end{tabular} & $\begin{array}{l}\text { Face-to-face advice, goal setting and } \\
\text { follow-up by phone counseling: The } \\
\text { intervention was verbal advice to } \\
\text { increase physical activity with exercise } \\
\text { goals written on a green prescription } \\
\text { card by the GP. The prescription was } \\
\text { then faxed to exercise specialists in } \\
\text { Sports Foundations who provided phone } \\
\text { support on three occasions over the } \\
\text { following three months to each } \\
\text { intervention patient and sent written } \\
\text { material including newsletters }(n=451) \\
\end{array}$ & $\begin{array}{l}\text { Doing nothing: The } \\
\text { control group received } \\
\text { usual care that may } \\
\text { have included some } \\
\text { verbal advice about } \\
\text { physical activity } \\
(\mathrm{n}=427)\end{array}$ & 12 months & $\begin{array}{l}\text { Minutes of leisure } \\
\text { exercise per week as } \\
\text { measured with a seif- } \\
\text { administered } \\
\text { questionnaire which } \\
\text { prompts recall of } \\
\text { physical act vity over } \\
\text { three months [50] }\end{array}$ & $\begin{array}{l}\text { Societal perspective } \\
\text { Intervention costs; health } \\
\text { funder costs; patient costs; } \\
\text { productivity costs }\end{array}$ \\
\hline $\begin{array}{l}\text { Sevick et al. } \\
\text { [43] }\end{array}$ & USA & \begin{tabular}{|l|} 
Adults aged $35-60$ years \\
recruited through mass media \\
(print, radio, TV), word of mouth \\
and recontacting volunteers from \\
previous studies. Participants \\
were sedentary but healthy \\
(meaning no history of \\
myocardial infarction, stroke, \\
insulin-dependent diabetes \\
mellitus, osteoporosis, or \\
osteoarthritis) \\
Mean age (years): (I) $46 ;$ (C) 46 \\
Males (\%): (I) $50 ;$ (C) 49
\end{tabular} & $\begin{array}{l}\text { Lifestyle intervention: Teaching of } \\
\text { behavior modification and cognitive- } \\
\text { behavior modification techniques for } \\
\text { behavior change in small group } \\
\text { meetings. During the 18-month tapered } \\
\text { phase, all participants received a } \\
\text { quarterly newsletter and a monthly } \\
\text { calendar of activities. }(n=121)\end{array}$ & \begin{tabular}{|l} 
Exercise prescription: \\
Participants in the \\
control group received \\
typical exercise \\
prescription as \\
described by the \\
American College of \\
Sports iledicine, \\
involving an exercise \\
intensity of $50 \%-85 \%$ \\
of maximal aerobic \\
pover and exercise of \\
20 o 60 minutes \\
duration at each \\
session. During the \\
18-month tapered \\
phase, all participants \\
received a quarterly \\
newsletter and a \\
monthly calendar of \\
activities. ( $n=114)$
\end{tabular} & 24 months & $\begin{array}{l}\text { Energy expenditure per } \\
\text { day from physical } \\
\text { activity using the 7-day } \\
\text { Physical Activity Recall } \\
\text { questionnaire [53] }\end{array}$ & $\begin{array}{l}\text { Payer perspective } \\
\text { Intervention staff time, } \\
\text { computerized tracking } \\
\text { system, curriculum } \\
\text { materials, printing and } \\
\text { postage, facilities, health } \\
\text { club memberships. }\end{array}$ \\
\hline
\end{tabular}

SQUASH = Short Questionnaire to Assess Health Enhancing Physical Activity, TMI = Telephone Motivational Interviewing, TPC = Tailored Printed Communication

a description of the population investigated including how the participants were recruited followed by mean age of the population and sex distribution, (I) refers to intervention group, (C) refers to control group, in case of more than one trial arm (1) refers to trial arm one, (2) refers to trial arm two and so on

${ }^{b}$ description of the intervention including the number of participants (n), in case of more than one trial arm (1) refers to trial arm one, (2) refers to trial arm two and so on

${ }^{c}$ description of the control group including the number of participants $(n)$

${ }^{\mathrm{d}}$ last follow-up time point 
Twenty-two interventions were analyzed in the twelve studies. The interventions investigated in eight studies were advice and goal setting conducted in different ways such as face-toface, by telephone, using printed material or web contact/communication with different kinds of follow-up support [36-39, 44-47]. Exercise classes were researched in two studies [40, 41]. One study investigated financial incentives [42] and one study examined teaching on behavioral change [43]. In seven studies, the control group did not receive any information regarding physical activity during the study period, unless it was part of usual care $[36,37$, 39, 40, 44-46]. The other five studies compared the intervention group to a contro' group that also received an intervention that aimed at increasing physical activity $[3841-43,47]$. As an example, in one study the control group received mailings unrelated to physical activity compared to the intervention arm with participants, who received telephone-based or printbased individually tailored feedback [44]. In another example, the control group received fixed financial incentives, and the intervention group received incentives based on the amount of physical activity [42].

The duration of follow-up was one month in one study [42], twelve months in eight studies $[37-41,44,45,47], 17$ months in one stuay [46] and 24 months in two studies [36, 43]. The effect on physical activity was measured with self-reported questionnaires in eight studies [36-38, 40, 41, 43, 45, 46] Two studies used pedometers in addition to activity logs and questionnaires to measure the outcome $[42,47]$ and one study used face-to-face interviews [44]. One study measured physical activity objectively by accelerometry [39].

Costs were assessed using different perspectives. Three studies conducted the analysis from a societal perspective and included intervention costs, costs to participants, healthcare costs and production losses [36, 37, 45]. Two studies included intervention costs, costs to participants and healthcare costs $[38,41]$. Three studies assessed intervention costs and costs to participants $[40,43,46]$ and one study included intervention costs and healthcare costs [39]. Three studies only included intervention costs [42, 44, 47]. In general, intervention costs were assessed using study records. Costs to participants and production losses were 
mainly quantified based on questionnaires. Healthcare costs were assessed using either questionnaires or healthcare practice records. A separate and detailed reporting of resource consumption and unit cost was not done in most of the studies, except for the ones originating from New Zealand [36-38] and a recent study from UK [39]. Costing year was not specifically reported in four studies [41, 43, 46, 47]. Only two studies separately reported fixed and variable costs $[45,46]$.

\subsection{Risk of bias and quality assessment}

Risk of bias was assessed for each study with the Cochrane risk of bias tool [24] and results are summarized in Table 3. Six out of twelve studies provided enough information to judge that random sequence generation and allocation concealment were adequate. Adequate blinding of personnel and blinding of outcome assessment was reported in four studies. Incomplete outcome data were addressed in eight studies. Risk of reporting bias was judged to be low in eleven studies. The quality assessment using the CHEC list [23] showed that most studies did not investigate costs from an appropriate perspective (societal), many studies did not report the costing year ana several studies did not conduct an appropriate sensitivity analysis (see electronic supplementary Table S1).

Table 3 Risk of bias summary table

\begin{tabular}{|c|c|c|c|c|c|c|c|}
\hline Reference & $\begin{array}{l}\text { Additional } \\
\text { references }\end{array}$ & $\begin{array}{l}\text { Ranciom } \\
\text { sequence } \\
\text { generation } \\
\text { (selection bias) }\end{array}$ & \begin{tabular}{|l|} 
Allocation \\
concealment \\
(selection \\
bias)
\end{tabular} & $\begin{array}{l}\text { Blinding of } \\
\text { personnel } \\
\text { (performance } \\
\text { bias) }\end{array}$ & \begin{tabular}{|l} 
Blinding of \\
outcome \\
assessment \\
(detection bias)
\end{tabular} & $\begin{array}{l}\text { Incomplete } \\
\text { outcome data } \\
\text { addressed } \\
\text { (attrition bias) }\end{array}$ & $\begin{array}{l}\text { Selective } \\
\text { reporting } \\
\text { (reporting bias) }\end{array}$ \\
\hline $\begin{array}{l}\text { Harris et al. } \\
{[39]}\end{array}$ & & + & + & - & + & + & + \\
\hline $\begin{array}{l}\text { Ewald et al. } \\
{[47]}\end{array}$ & {$[5 \overline{5}, \overline{56}]$} & + & + & + & + & $?$ & + \\
\hline $\begin{array}{l}\text { Golsteijn et al. } \\
{[45]}\end{array}$ & {$[57]$} & $?$ & $?$ & $?$ & $?$ & + & + \\
\hline lliffe et al. [40] & & + & + & - & - & + & + \\
\hline $\begin{array}{l}\text { Leung et al. } \\
{[38]}\end{array}$ & {$[58]$} & - & - & + & + & + & + \\
\hline Elley et al. [36] & {$[59]$} & + & + & + & + & + & + \\
\hline $\begin{array}{l}\text { Van Keulen et } \\
\text { al. [46] }\end{array}$ & {$[60]$} & + & $?$ & $?$ & ? & + & + \\
\hline $\begin{array}{l}\text { Finkelstein et } \\
\text { al. [42] }\end{array}$ & & + & + & - & $?$ & + & + \\
\hline $\begin{array}{l}\text { Sevick et al. } \\
{[44]}\end{array}$ & {$[61]$} & $?$ & $?$ & ? & ? & $?$ & $?$ \\
\hline $\begin{array}{l}\text { Isaacs et al. } \\
{[41]}\end{array}$ & & + & + & - & - & + & + \\
\hline Elley et al. [37] & {$[62]$} & + & $?$ & $?$ & $?$ & $?$ & + \\
\hline $\begin{array}{l}\text { Sevick et al. } \\
{[43]}\end{array}$ & {$[63-65]$} & $?$ & $?$ & + & + & - & + \\
\hline
\end{tabular}


Coding of judgment: "+" low risk of bias; "?" unclear risk of bias; "-" high risk of bias 


\subsection{Results of trial-based economic evaluations}

Effects of the interventions varied widely. The highest effect on physical activity was seen in an intervention using financial incentives (Table 4). The effect was a gain of 1.17 MET-hours per day. However, it should be considered that this study had a follow-up duration of 4 weeks, which is much smaller than all the other studies, which had a follow-up of at least 1 year. Another intervention that was based on printed individualized motivationally tailored feedback showed a gain of 1.01 MET-hours per day, which can be considered equivalent to 20 minutes of moderate physical activity per day [44]. Five interventions gained between 0.5 and 1 MET-hour per day. These interventions included behavior change courseling or teaching, a combination of advice, goal setting and follow-up counseling, individualized feedback by telephone and instructor-led walking [36, 41, 43, 44, 47]. One intervention that used computer-tailored physical activity advice communicated via website and email had a negative effect (-0.06 MET-hours per day) [45]. All the other interventions had an effect between 0.1 and 0.5 MET-hours per day.

Costs of interventions varied widely. The most expensive interventions were based on individualized motivationally tailored feedback communicated via telephone (US\$1260 per person) or print (US\$638 per person) [44]. However, these costs included recruitment and facility costs that were not included in any of the other studies. Four other interventions had costs higher than U\$\$300 per person: One intervention combining advice, goal setting and follow-up counseling, two interventions based on exercise classes, and one behavior change teaching intervention $[38,40,41,43]$. Seven interventions had costs lower than US\$100 per person: three interventions with computer tailored physical activity advice communicated via print, two similar interventions communicated via web, one individualized step-related goal setting intervention plus one intervention combining advice, goal setting and follow-up counseling $[36,39,45,46]$. All the other interventions had costs between US\$100 per person and US\$250 per person. 
The ICER varied widely among the interventions (Fig. 2). Four interventions showed an ICER below our benchmark between US\$0.44 and US\$0.63 per MET-hour gained, which is based on the health care costs and productivity losses of physical inactivity in Switzerland. These four interventions were based on individualized advice delivered in four different ways [45]: print (postal mail) or web (website and email) and in a basic form (standard advice) or with additional environmental components (e.g., walking and cycling routes and physical activity possibilities and initiatives in participants' own neighborhood and home exercises) One other intervention that was based on behavior change counseling by telephone had an ICER of US\$0.64 per MET-hour gained [47]. One pedometer-based individualized step-related goal setting intervention had an ICER of US\$0.67 per MET-hour gained [391. Another intervention was based on face-to-face advice, goal setting, follow-up face-to-face meeting and follow-up telephone counseling [36]. This intervention had an ICER of U $\$ \$ 0.85$ per MET-hour gained. All other interventions had an ICER above US\$1.00 por MET-hour gained. 
Table 4 Detailed MET-hours gained, intervention costs and ICER of included studies

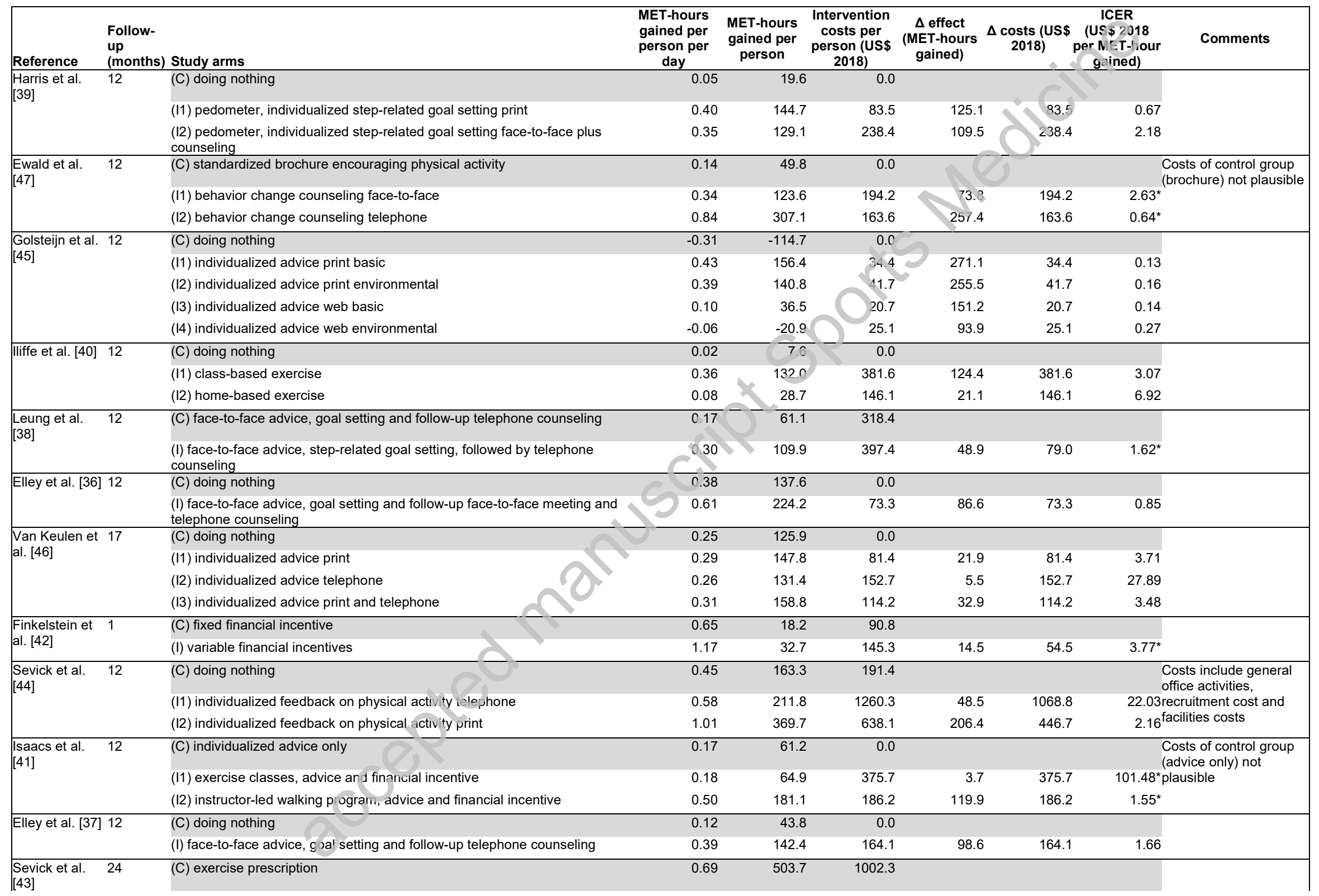


(I) behavior change teaching face-to-face

(1) "doing nothing"; C = comparator; I = intervention; $\Delta=$ intervention - control group; ICER = incremental cost-effectiveness ratio; MET-hours gained per person = MET-hours gained per person per day multiplied with the number of days of follow-up to make the effect comparable to the costs and, therefore, allow to compare interventions with different follow-up times. 


\section{Discussion}

To the best of our knowledge, this study is the first to systematically review RCT-based economic evaluations of physical activity interventions for primary prevention or health promotion in adults. Four interventions that delivered individualized advice via print or web showed best value (physical activity gains) for money (intervention costs) with ICERs below the benchmark between US\$0.44 and US\$0.63 per MET-hour gained [45]. However, cost. effectiveness results varied widely among interventions and only a small number of interventions would be cost-effective according to the benchmark applied. Furthermore, this study shows that trial-based evidence on cost-effectiveness of physical activity interventions is relatively scarce, confirming a finding from the first Economics of Physical Inactivity Consensus (EPIC) conference [15].

Our focus on the rigorous RCT study design may be one reason why we found only a small number of cost-effective interventions [17]. Wu et al. [17] also showed higher effects in studies using subjective physical activity measures compared to objective measures. Therefore, it seems noteworthy that one study using accelerometry showed an ICER just above the benchmark although rather conservative results would be expected with such an objective measure [39]. Anothe study using pedometers also showed an ICER very close to the benchmark [47]. This intervention that was based on behavior change counseling by telephone, had a reasonable incremental effect of $0.71 \mathrm{MET}$-hours gained per person per day and showed an ICER of US\$0.64 per MET-hour gained [47]. However, the ICER for this intervent on was based on a comparator intervention other than "doing nothing". It seems likely that the ICER would lie below the benchmark if compared to "doing nothing". One other intervention was dominant, i.e. better and cheaper than the comparator [43]. However, the comparator was an active one (specifically, exercise prescription) and, therefore, the ICER cannot be directly compared to ICERs from studies with a "doing nothing" comparator.

Intervention effects and costs from the studies included in our analysis are comparable to previous findings from studies that investigated evidence from trials (controlled trial, pre-post 
trial, or postmeasure-comparison approach) or model-based economic evaluations [17, 25 , 66]. The highest effect on physical activity (gain of 1.17 MET-hours per day compared to baseline) was observed in an intervention using variable financial incentives [42]. However, this study had a very short follow-up of 4 weeks and the intervention effect may not lead to substantial health benefits in a longer-term perspective. The second highest effect (gain of 1.01 MET-hours per day) was shown for a print-based individualized motivationally tailored feedback intervention [44]. These interventions with the highest effect required more resources and therefore showed high costs. Although such more intensive interventions may not be cost-effective at the population level, they may be cost-effective in more targeted populations [17]. In Switzerland for example, we see a higher prevalence of physical inactivity in the French- and Italian-speaking language regions compared to the Germanspeaking region [33]. In addition, populations with lower socioeconomic status show higher prevalence of physical inactivity. Targeting populations with similar cultural and socioeconomic characteristics may increase cost effectiveness of physical activity interventions.

The intervention by Goldsteijn et al. [45] that provided individualized advice delivered via web and included additional environmental components is a good example for showing a problematic aspect of cost-effectiveness analyses in the field. The intervention itself had a negative effect of $-0.06 \mathrm{MET}$-hours gained per person per day when comparing physical activity at the one year follow-up versus baseline. However, compared to the "doing nothing" control group the incremental effect was 0.26 MET-hours gained per person per day, which is equivalent to approximately five minutes of moderate physical activity per person per day. Although this is a positive effect, it can be considered a relatively low incremental physical activity gain that is not sufficient to lead to substantial health benefits [67]. The annual intervention costs were US $\$ 25.14$ per person. This leads to an ICER of US $\$ 0.27$ per METhour gained, which is below the benchmark. Therefore, the intervention is considered costeffective although the physical activity gain can be considered as not sufficient to lead to substantial health benefits. This issue was already raised by Wu et al. [17], who showed that 
some interventions that increased physical activity levels only by small amounts, such as stair climbing prompts, may be very cost-effective due to the very low intervention costs. Consequently, relying on cost-effectiveness alone might favor interventions that are unable to add substantial health benefits. The specifics of each intervention should therefore be considered and additional criteria such as minimal clinically relevant effectiveness thresholds might be used in future health policy decision-making.

Cost-effectiveness may vary among settings and a previous study showed the limitea comparability, generalizability and transferability of results from economic evaluations of physical activity interventions due to a high variability in costing methods [68]. Trial-based and model-based economic evaluations are complementary methods to assess costeffectiveness [13]. Our research shows the limited evidence avaliable from trial-based economic evaluations. Consequently, transferability of trial-based economic evaluations and the use of data from trial-based economic evaluations as input for model-based economic evaluations gain in importance. As explained above, in model-based economic evaluations, data on the effect and the costs from different sources are combined in a decision-analytic model.

We therefore agree with the EPIC statement that asks for high-quality RCTs with appropriate power and follow-up [15]. The statement also discusses other methodological challenges for economic evaluations of physical activity interventions such as the objective measurement of the intervention effect. Focusing more on the health economic aspects, we would stress the need to use available guidelines when conducting and reporting economic evaluations of physical activity interventions [23, 69]. Furthermore, we see an urgent need in reporting resource consumption and unit costs separately. This would not only increase transparency but also transferability of the results to other settings. In addition, the separate reporting of fixed and variable costs would facilitate the consideration of the cost-effectiveness when scaling-up physical activity interventions [70]. When reporting costs and effects, future studies should not only report means but also descriptors of statistical uncertainty. Another 
requirement for future studies is the use of "doing nothing" control groups, as this would increase the comparability of ICERs among studies.

Several limitations need to be considered. The studies included in our analysis investigated different populations, comparators, settings, and follow-up durations and used different outcome measures. Therefore, interventions were too diverse to warrant mathematical comparison and it was decided to not provide summary estimates using meta-analysis techniques. In order to improve comparability, effect measures were standardized to METhours gained per person per day. Although this method was used in previous studies, it may have some limitations when applied to broad outcomes such as step gains or proportions of populations meeting physical activity guidelines $[17,25]$. In addition, many studies did not report sufficient statistical detail and, therefore, we were not able to properly address uncertainty. In order to assess the level of cost-effectiveness, we introduced a benchmark similar to that used in previous studies $[17,25]$. Our benchmark was based on the health care costs and productivity losses of physical inacivity in Switzerland. Settings with different levels of prevalence of physical inactivity, heaith care spending or wages might choose different benchmarks for assessing cost-effectiveness of interventions to increase physical activity. The ICERs estimated in our study are based on the intervention costs and do not include potentially saved health care costs. Furthermore, we focused on interventions that can be implemented on a population-level and therefore excluded studies investigating the workplace setting. Some interventions focusing on the workplace setting have been previously shown to be cost-effective [71]. By limiting the study design to RCTs, we also excluded interventions targeting the built environment [17, 25, 72, 73]. As we excluded studies that did not report specific physical activity outcomes, we did not include studies only reporting quality-adjusted life-years as part of pure cost-utility analyses [74-76]. These studies showed varying results in terms of cost per quality-adjusted life-years gained by physical activity interventions. 


\section{Conclusion}

We found evidence from RCTs indicating cost-effectiveness of some physical activity interventions. However, the majority of interventions assessed would not be cost-effective according to the benchmark applied. Some interventions increased physical activity levels only by small amounts, but were still cost-effective due to the very low intervention costs. Some interventions with relatively large intervention effects required more resources and, therefore, showed higher costs. Although such more intensive interventions may not be costeffective at the population level, they may be cost-effective in more targeted populations (e.g. for Switzerland: populations with similar cultural background or with similar socioeconomic status).

Due to the relatively scarce trial-based evidence on the cost-effectiveness of physical activity interventions, we recommend that future studies investigating the efficacy or effectiveness of interventions aimed at reducing physical inactivity consider costs as an additional outcome of the study in order to assess cost-effectiveness Such studies may not only investigate physical activity but overall lifestyle and consider well-being as an additional, separate outcome. 
Author Contributions: RM and MS conceived the design of the study. RM and RF screened the studies. RM and MES extracted the data. RM, MES, SW, AST, MS were involved in the data analysis. RM drafted the manuscript. All authors were involved in the interpretation of the data and commented on and edited the final manuscript.

\section{Compliance with Ethical Standards}

Funding: No sources of funding were used to assist in the preparation of this article.

Conflicts of Interest: Renato Mattli, Renato Farcher, Maria-Eleni Syleouni, Simon Vieser, Nicole Probst-Hensch, Arno Schmidt-Trucksäss and Matthias Schwenkglenks declare that they have no conflicts of interest relevant to the content of this review

Data Availability: Any additional information (e.g. review protocol) is available upon request from the corresponding author. 


\section{References}

1. Ding D, Kolbe-Alexander T, Nguyen B, Katzmarzyk PT, Pratt M, Lawson KD. The economic burden of physical inactivity: a systematic review and critical appraisal. Br J Sports Med. 2017;51(19):1392-409. doi:10.1136/bjsports-2016-097385.

2. Ding D, Lawson KD, Kolbe-Alexander TL, Finkelstein EA, Katzmarzyk PT, van Mechelen W, et al. The economic burden of physical inactivity: a global analysis of major non-communicable diseases. Lancet. 2016;388(10051):1311-24. doi:10.1016/s0140-6736(16)30383-x.

3. Lee IM, Shiroma EJ, Lobelo F, Puska P, Blair SN, Katzmarzyk PT. Effect of physical inactivity on major non-communicable diseases worldwide: an analysis of burden of disease and life expectancy. Lancet. 2012;380(9838):219-29. doi:10.1016/s0140-6736(12)61031-9.

4. Blondell SJ, Hammersley-Mather R, Veerman JL. Does physical activity prevent cognitive decline and dementia?: A systematic review and meta-analysis of longitudinal studies. BMC Public health. 2014;14:510. doi:10.1186/1471-2458-14-510.

5. Schuch FB, Vancampfort D, Firth J, Rosenbaum S, Ward PB, Silva ES, et al. Physical activity and incident depression: A meta-analysis of prospective cohort studies. Am J Psychiatry. 2018;175(7):63148. doi:10.1176/appi.ajp.2018.17111194.

6. Shiri R, Falah-Hassani K. Does leisure time physical activity protect against low back pain? Systematic review and meta-analysis of 36 prospective cohort studies. Br J Sports Med. 2017;51(19):1410-8. doi:10.1136/bjsports-2016-097352.

7. Foster C, Hillsdon M, Thorogood M, Kaur A, Wedatilake T. Interventions for promoting physical activity. Cochrane Database Syst Rev. 2005(1). doi:10.1002/14651858.CD003180.pub2.

8. Buxton MJ, Drummond MF, Van Hout BA, Prince RL, Sheldon TA, Szucs T, et al. Modelling in economic evaluation: an unavoidable fact of life. Health Econ. 1997;6(3):217-27.

9. Ramsey S, Willke R, Briggs A, Brown R, Buxton M, Chawla A, et al. Good research practices for costeffectiveness analysis alongside clinical trials: the ISPOR RCT-CEA task force report. Value Health. 2005;8(5):521-33. doi:10.1111/j.1524-4733.2005.00045.x.

10. Brennan A, Akehurst R. Modelling in health economic evaluation. What is its place? What is its value? Pharmacoeconomics. 2000;17(5):445-59.

11. Sculpher MJ, Claxton K, Drummond M, MCCabe C. Whither trial-based economic evaluation for health care decision making? Health Econ. 2006;15(7):677-87. doi:10.1002/hec.1093.

12. Rittenhouse B. Uses of models in economic evaluations of medicines and other health technologies. London: Office of Health Economics1996.

13. Drummond $M$, Sculpher $M$. Common methodological flaws in economic evaluations. Med Care. 2005;43(7 Suppl):5-14.

14. Abu-Omar K, Rutten A Burlacu I, Schatzlein V, Messing S, Suhrcke M. The cost-effectiveness of physical activity interventions: A systematic review of reviews. Preventive medicine reports.

2017;8:72-8. doi:10.1016/j.pmedr.2017.08.006.

15. Davis JC, Vernagen E, Bryan S, Liu-Ambrose T, Borland J, Buchner D, et al. 2014 consensus statement from the first Economics of Physical Inactivity Consensus (EPIC) conference (Vancouver). Br J Sports Mied. 2014;48(12):947-51. doi:10.1136/bjsports-2014-093575.

16. Foster C, Richards J, Thorogood M, Hillsdon M. Remote and web 2.0 interventions for promoting physical activity. Cochrane Database Syst Rev. 2013(9). doi:10.1002/14651858.CD010395.pub2.

17. Wu S, Cohen D, Shi Y, Pearson M, Sturm R. Economic analysis of physical activity interventions. Am J Prev Med. 2011;40(2):149-58. doi:10.1016/j.amepre.2010.10.029.

18. Thielen FW, Van Mastrigt G, Burgers LT, Bramer WM, Majoie H, Evers S, et al. How to prepare a systematic review of economic evaluations for clinical practice guidelines: database selection and search strategy development (part 2/3). Expert Rev Pharmacoecon Outcomes Res. 2016;16(6):70521. doi:10.1080/14737167.2016.1246962.

19. van Mastrigt GA, Hiligsmann M, Arts JJ, Broos PH, Kleijnen J, Evers SM, et al. How to prepare a systematic review of economic evaluations for informing evidence-based healthcare decisions: a fivestep approach (part 1/3). Expert Rev Pharmacoecon Outcomes Res. 2016;16(6):689-704.

doi:10.1080/14737167.2016.1246960. 
20. Wijnen B, Van Mastrigt G, Redekop WK, Majoie H, De Kinderen R, Evers S. How to prepare a systematic review of economic evaluations for informing evidence-based healthcare decisions: data extraction, risk of bias, and transferability (part 3/3). Expert Rev Pharmacoecon Outcomes Res. 2016;16(6):723-32. doi:10.1080/14737167.2016.1246961.

21. World Bank. World Bank country and lending groups. 2018.

https://datahelpdesk.worldbank.org/knowledgebase/articles/906519-world-bank-country-andlending-groups. Accessed 10 November 2018.

22. McGowan J, Sampson M, Salzwedel DM, Cogo E, Foerster V, Lefebvre C. PRESS Peer Review of Electronic Search Strategies: 2015 guideline statement. J Clin Epidemiol. 2016;75:40-6. doi:10.1016/j.jclinepi.2016.01.021.

23. Evers $S$, Goossens $M$, de Vet $H$, van Tulder M, Ament A. Criteria list for assessment of methodological quality of economic evaluations: Consensus on Health Economic Criteria. Int J Technol Assess Health Care. 2005;21(2):240-5.

24. Higgins JPT, Green S. Cochrane handbook for systematic reviews of interventions version 5.1 .0 [updated March 2011]. The Cochrane Collaboration; 2011.

25. Laine J, Kuvaja-Kollner V, Pietila E, Koivuneva M, Valtonen $H$, Kankaanpaa E. Cost-effectiveness of population-level physical activity interventions: a systematic review. Am J Health Promot. 2014;29(2):71-80. doi:10.4278/ajhp.131210-LIT-622.

26. Canning KL, Brown RE, Jamnik VK, Salmon A, Ardern Cl, Kuk JL. Individuals underestimate moderate and vigorous intensity physical activity. PLoS One. 2014;9(5):e97927.

doi:10.1371/journal.pone.0097927.

27. Cerin E, Cain KL, Oyeyemi AL, Owen N, Conway TL, Cochrane T, et al. Correlates of agreement between accelerometry and aelf-reported physical activity. Nied Sci Sports Exerc. 2016;48(6):107584. doi:10.1249/mss.0000000000000870.

28. Van Holle V, De Bourdeaudhuij I, Deforche B, Van Cauwenberg J, Van Dyck D. Assessment of physical activity in older Belgian adults: validity and rel ability of an adapted interview version of the long International Physical Activity Questionnaire (IPAQ-L). BMC Public Health. 2015;15:433. doi:10.1186/s12889-015-1785-3.

29. Drummond M, Weatherly H, Claxton K, Ferguson B, Godfrey C, Rice N, et al. Assessing the challenges of applying standard methods of economic evaluation to public health interventions. York: Public Health Research Consortium2008,

30. World Bank. PPP conversion factor, GDP (LCU per international \$). 2019.

https://data.worldbank.org/indicator/pa.nus.ppp. Accessed 20 February 2019.

31. Federal Reserve Bank of St. Louis. Consumer price index: Total all items for the United States, index 2015=100, annual, not seasonally adjusted. 2019. https://fred.stlouisfed.org. Accessed 03 June 2019.

32. WHO. Global recommendations on physical activity for health. Geneva, Switzerland2010.

33. Mattli R, Wieser S, Probst-Hensch N, Schmidt-Trucksass A, Schwenkglenks M. Physical inactivity caused economic burden depends on regional cultural differences. Scand J Med Sci Sports. 2019;29(1):95-104. doi:10.1111/sms.13311.

34. Federal Statistical Office. Kosten und Finanzierung des Gesundheitswesens seit 1960. 2019. https.//www.bfs.admin.ch/bfs/de/home/statistiken/gesundheit/kostenfinanzierung/kosten.assetdetail.8726007.html. Accessed 20 June 2019.

35. Federal Statistical Office. Swiss wage index: index and variation on the base of $2010=100$ (NOGA08). 2019. https://www.bfs.admin.ch/bfs/de/home/statistiken/arbeit-erwerb/loehneerwerbseinkommen-arbeitskosten/lohnentwicklung.assetdetail.8046234.html. Accessed 20 June 2019.

36. Elley CR, Garrett S, Rose SB, O'Dea D, Lawton BA, Moyes SA, et al. Cost-effectiveness of exercise on prescription with telephone support among women in general practice over 2 years. $\mathrm{Br} \mathrm{J}$ Sports Med. 2011;45(15):1223-9.

37. Elley CR, Kerse N, Arroll B, Swinburn B, Ashton T, Robinson E. Cost-effectiveness of physical activity counselling in general practice. N Z Med J. 2004;117(1207). 
38. Leung W, Ashton T, Kolt GS, Schofield GM, Garrett N, Kerse N, et al. Cost-effectiveness of pedometer-based versus time-based Green Prescriptions: The Healthy Steps Study. Aust J Prim Health. 2012;18(3):204-11. doi:10.1071/PY11028.

39. Harris T, Kerry S, Victor C, lliffe S, Ussher M, Fox-Rushby J, et al. A pedometer-based walking intervention in 45- to 75-year-olds, with and without practice nurse support: The PACE-UP three-arm cluster RCT. Health Technol Assess. 2018;22(37):1-273. doi:10.3310/hta22370.

40. lliffe S, Kendrick D, Morris R, Masud T, Gage H, Skelton D, et al. Multicentre cluster randomised trial comparing a community group exercise programme and home-based exercise with usual care for people aged 65 years and over in primary care. Health Technol Assess. 2014;18(49):1-105. doi:10.3310/hta18490.

41. Isaacs AJ, Critchley JA, Tai SS, Buckingham K, Westley D, Harridge SDR, et al. Exercise evaluation randomised trial (EXERT): A randomised trial comparing GP referral for leisure centre-based exercise, community-based walking and advice only. Health Technol Assess. 2007;11(10):iii-104.

42. Finkelstein EA, Brown DS, Brown DR, Buchner DM. A randomized study of financial incentives to increase physical activity among sedentary older adults. Prev Med. 2008;47(2):182-7.

doi:10.1016/j.ypmed.2008.05.002.

43. Sevick MA, Dunn AL, Morrow MS, Marcus BH, Chen GJ, Blair SN. Cost-effectiveness of lifestyle and structured exercise interventions in sedentary adults. Results of project ACIIVE. Am J Prev Med. 2000;19(1):1-8. doi:10.1016/S0749-3797(00)00154-9.

44. Sevick MA, Napolitano MA, Papandonatos GD, Gordon AJ, Reiser LM, Marcus BH. Cost-

effectiveness of alternative approaches for motivating activity in sedentary adults: Results of Project STRIDE. Prev Med. 2007;45(1):54-61. doi:10.1016/j.ypmed.2007.04.008.

45. Golsteijn RHJ, Peels DA, Evers SMAA, Bolman C, Mudde AN de Vries $\mathrm{H}$, et al. Cost-effectiveness and cost-utility of a web-based or print-delivered tailored intervention to promote physical activity among adults aged over fifty: An economic evaluation of the Active Plus intervention. Int J Behav Nutr Phys Act. 2014;11(1):1-17. doi:10.1186/s12966-0.14-0122-z.

46. van Keulen HM, Bosmans JE, van Tulder MW Severens JL, de Vries H, Brug J, et al. Costeffectiveness of tailored print communication, telephone motivational interviewing, and a combination of the two: Results of an economic evaluation alongside the Vitalum randomized controlled trial. Int J Behav Nutr Phys Act. 2010;7. doi:10.1186/1479-5868-7-64.

47. Ewald B, Stacey F, Johnson N, Plotnikoff RC, Holliday E, Brown W, et al. Physical activity coaching by Australian Exercise Physiologists is cost effective for patients referred from general practice. Aust N Z J Public Health. 2018;42(1):12-5. doi:10.1111/1753-6405.12733.

48. Wendel-Vos GC, Schuit AJ Saris WH, Kromhout D. Reproducibility and relative validity of the short questionnaire to assess health-enhancing physical activity. J Clin Epidemiol. 2003;56(12):11639.

49. Stewart AL, Gillis D, Grossman M, Castrillo M, Pruitt L, McLellan B, et al. Diffusing a researchbased physical activity promotion program for seniors into diverse communities: CHAMPS III. Prev Chronic Dis. 2006;3(2):A51.

50. Arroll B, Jackson R, Beaglehole R. Validation of a three-month physical activity recall questionnaire with a seven-day food intake and physical activity diary. Epidemiology. 1991;2(4):2969.

51. McLean G, Tobias M. The New Zealand Physical Activity Questionnaires: Report on the validation and use of the NZPAQ-LF and NZPAQ-SF self-report physical activity survey instruments. Wellington, New Zealand: Sport and Recreation New Zealand (SPARC)2004.

52. Resnicow K, McCarty F, Blissett D, Wang T, Heitzler C, Lee RE. Validity of a modified CHAMPS physical activity questionnaire among African-Americans. Med Sci Sports Exerc. 2003;35(9):1537-45. doi:10.1249/01.mss.0000084419.64044.2b.

53. Sallis JF, Haskell WL, Wood PD, Fortmann SP, Rogers T, Blair SN, et al. Physical activity assessment methodology in the Five-City Project. Am J Epidemiol. 1985;121(1):91-106.

doi:10.1093/oxfordjournals.aje.a113987. 
54. Hillsdon M, Thorogood M, White I, Foster C. Advising people to take more exercise is ineffective: a randomized controlled trial of physical activity promotion in primary care. Int J Epidemiol. 2002;31(4):808-15. doi:10.1093/ije/31.4.808.

55. James EL, Ewald B, Johnson N, Brown W, Stacey FG, McElduff P, et al. Efficacy of GP referral of insufficiently active patients for expert physical activity counseling: protocol for a pragmatic randomized trial (The NewCOACH trial). BMC Fam Pract. 2014;15:218. doi:10.1186/s12875-0140218-1.

56. James EL, Ewald BD, Johnson NA, Stacey FG, Brown WJ, Holliday EG, et al. Referral for expert physical activity counseling: A pragmatic RCT. Am J Prev Med. 2017;53(4):490-9.

doi:10.1016/j.amepre.2017.06.016.

57. Peels DA, Bolman C, Golsteijn RH, De Vries H, Mudde AN, van Stralen MM, et al. Differences in reach and attrition between web-based and print-delivered tailored interventions among adults over 50 years of age: clustered randomized trial. J Med Internet Res. 2012;14(6):e179.

doi:10.2196/jmir.2229.

58. Kolt GS, Schofield GM, Kerse N, Garrett N, Ashton T, Patel A. Healthy Steps trial: pedometerbased advice and physical activity for low-active older adults. Ann Fam Med. 2012;10(3):206-12. doi:10.1370/afm.1345.

59. Rose SB, Lawton BA, Elley CR, Dowell AC, Fenton AJ. The 'Women's Lifestyie Study', 2-year randomized controlled trial of physical activity counselling in primary health care: rationale and study design. BMC Public Health. 2007;7:166. doi:10.1186/1471-2458-7-166.

60. van Keulen HM, Mesters I, Brug J, Ausems M, Campbell M, Resnicow K, et al. Vitalum study design: RCT evaluating the efficacy of tailored print communication and telephone motivational interviewing on multiple health behaviors. BMC Public Health. 2008;8:216. doi:10.1186/1471-2458-8216.

61. Marcus BH, Napolitano MA, King AC, Lewis BA, Whiteley JA, Albrecht AE, et al. Examination of print and telephone channels for physical activity p omotion: Rationale, design, and baseline data from Project STRIDE. Contemp Clin Trials. 2007;28(1):90-104. doi:10.1016/j.cct.2006.04.003.

62. Elley CR, Kerse N, Arroll B, Robinson E. Effectiveness of counselling patients on physical activity in general practice: cluster randomised controlied trial. BMJ. 2003;326(7393):793.

doi:10.1136/bmj.326.7393.793.

63. Dunn AL, Garcia ME, Marcus BH, Kampert JB, Kohl HW, Blair SN. Six-month physical activity and fitness changes in Project Active, a randomized trial. Med Sci Sports Exerc. 1998;30(7):1076-83.

64. Dunn AL, Marcus BH, Kampert JB, Garcia ME, Kohl HW, 3rd, Blair SN. Comparison of lifestyle and structured interventions to increase physical activity and cardiorespiratory fitness: a randomized trial. JAMA. 1999;281(4):327-34.

65. Kohl HW, 3rd, Dum AL, Marcus BH, Blair SN. A randomized trial of physical activity interventions: design and baseline data from project active. Med Sci Sports Exerc. 1998;30(2):275-83.

66. Muller-Riem enschneider F, Reinhold T, Willich SN. Cost-effectiveness of interventions promoting physical activity Br J Sports Med. 2009;43(1):70-6. doi:10.1136/bjsm.2008.053728.

67. U.S. Department of Health and Human Services. Physical activity guidelines for Americans, 2nd edition 2018.

68. Wolfenstetter SB, Wenig CM. Economic evaluation and transferability of physical activity programmes in primary prevention: a systematic review. Int J Environ Res Public Health. 2010;7(4):1622-48. doi:10.3390/ijerph7041622.

69. Husereau D, Drummond M, Petrou S, Carswell C, Moher D, Greenberg D, et al. Consolidated Health Economic Evaluation Reporting Standards (CHEERS) statement. Value Health. 2013;16(2):e1-5. doi:10.1016/j.jval.2013.02.010.

70. Reis RS, Salvo D, Ogilvie D, Lambert EV, Goenka S, Brownson RC. Scaling up physical activity interventions worldwide: stepping up to larger and smarter approaches to get people moving. Lancet. 2016;388(10051):1337-48. doi:10.1016/s0140-6736(16)30728-0. 
71. van Dongen JM, Proper KI, van Wier MF, van der Beek AJ, Bongers PM, van Mechelen W, et al. A systematic review of the cost-effectiveness of worksite physical activity and/or nutrition programs. Scand J Work Environ Health. 2012;38(5):393-408. doi:10.5271/sjweh.3275.

72. Cavill N, Kahlmeier S, Rutter H, Racioppi F, Oja P. Economic analyses of transport infrastructure and policies including health effects related to cycling and walking: A systematic review. Transp Policy (Oxf). 2008;15(5):291-304. doi:https://doi.org/10.1016/j.tranpol.2008.11.001.

73. Lewis C, Ubido J, Holford R, Scott-Samuel A. Prevention programmes cost-effectiveness review: Physical activity. Liverpool2010.

74. Chen IJ, Chou CL, Yu S, Cheng SP. Health services utilization and cost utility analysis of a walking program for residential community elderly. Nurs Econ. 2008;26(4):263-9.

75. Munro JF, Nicholl JP, Brazier JE, Davey R, Cochrane T. Cost effectiveness of a community based exercise programme in over 65 year olds: cluster randomised trial. J Epidemiol Community Health. 2004;58(12):1004-10. doi:10.1136/jech.2003.014225.

76. Schulz DN, Smit ES, Stanczyk NE, Kremers SP, de Vries H, Evers SM. Economic evaluation of a webbased tailored lifestyle intervention for adults: findings regarding cost-effectiveness and cost-utility from a randomized controlled trial. J Med Internet Res. 2014;16(3):e91. doi:10.2196/jmir.3159. 


\section{Figure Captions and Legends}

Fig. 1 PRISMA flow diagram of the systematic review

Fig. 2 Incremental intervention costs and MET-hours gained (ICERs) in trial-based economic evaluations of physical activity interventions

Legend: $\Delta$ refers to intervention minus comparator. The results from the study by Sevick et al. [43] were removed from the figure, as the cost difference was negative (US\$ -654); this was based on a comparator intervention other than "doing nothing" (specifically, exercise prescription). 


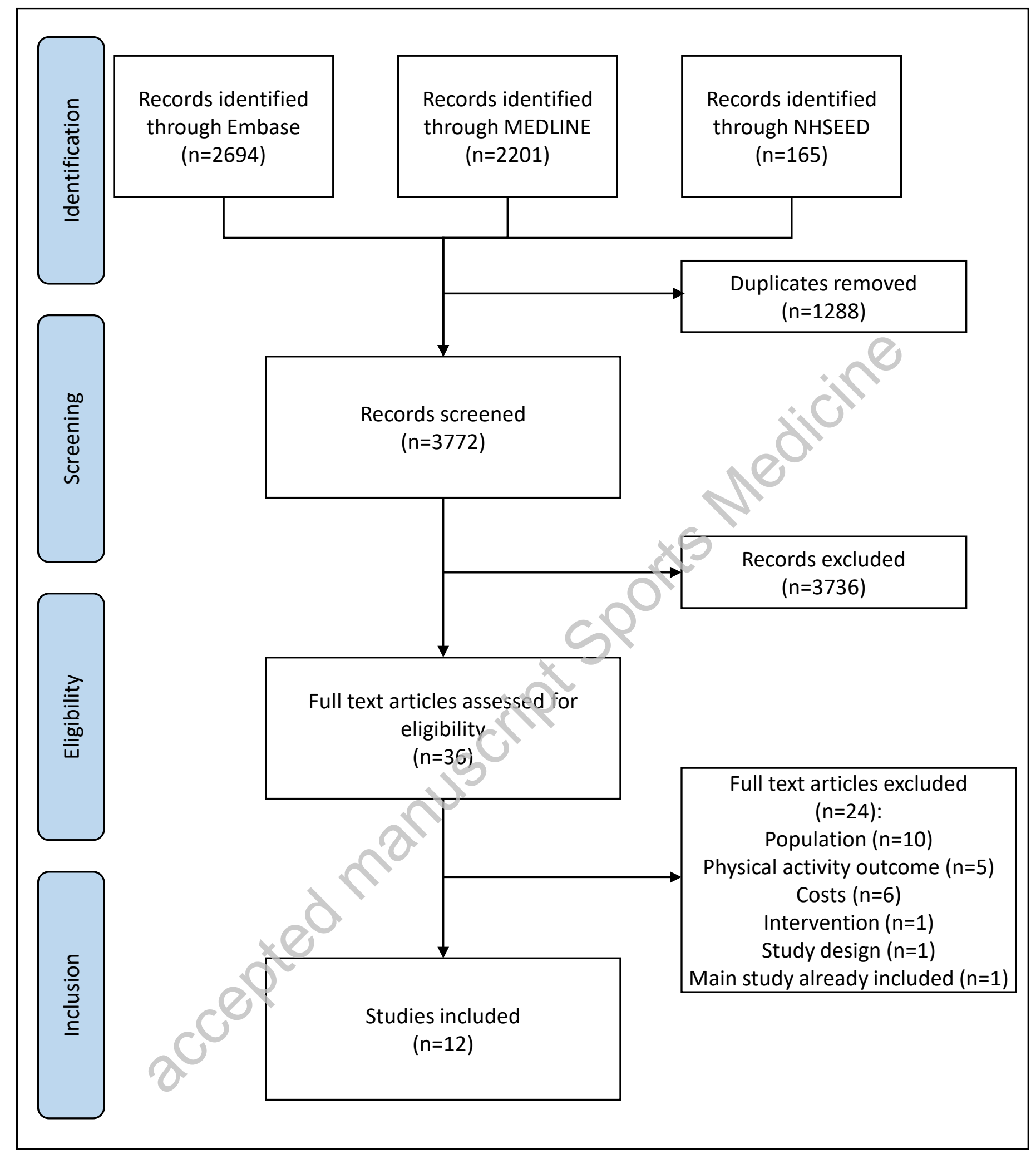




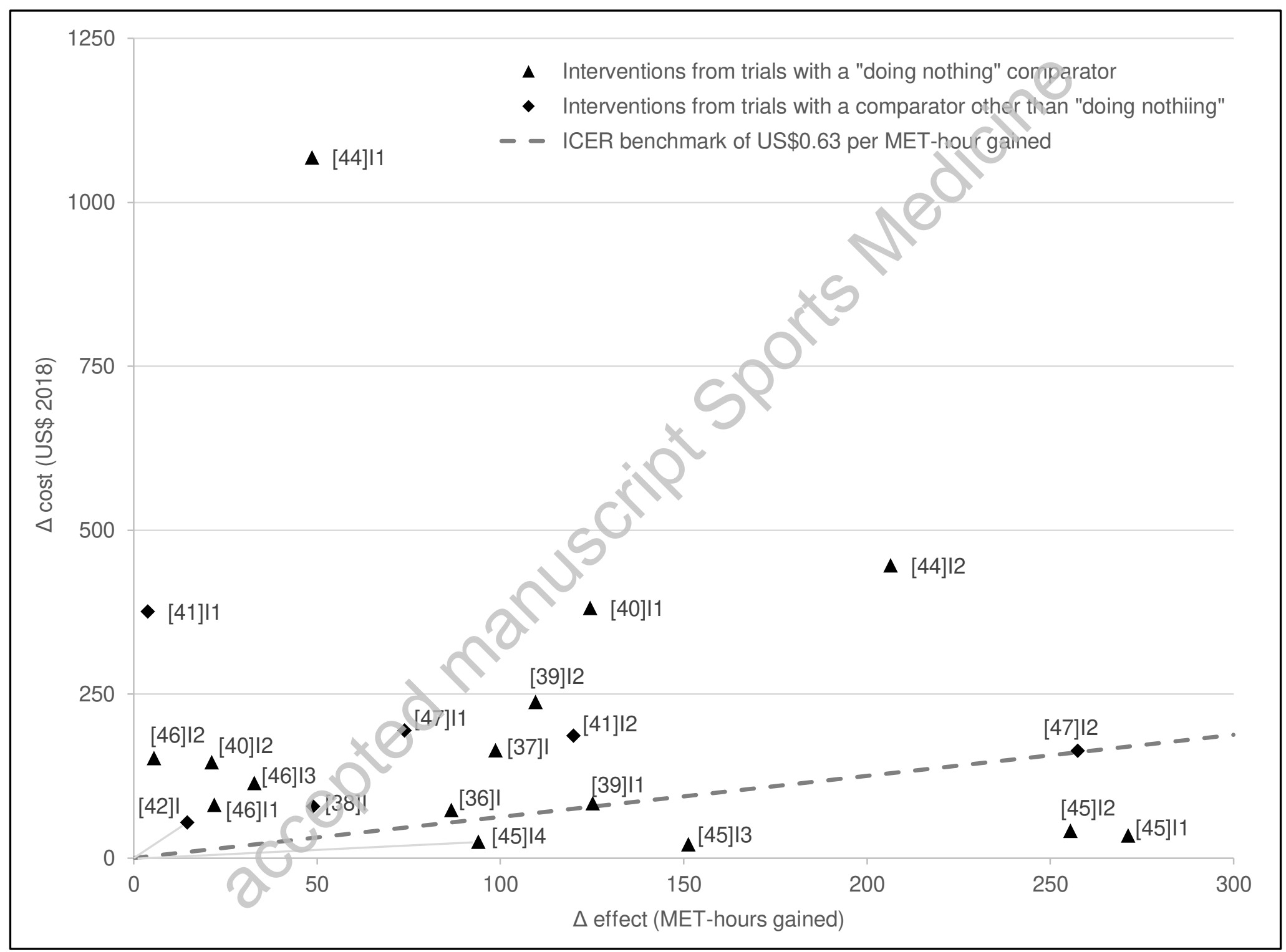

